\title{
Giant-cell tumour of the lumbar spine. Case report
}

\author{
$\mathrm{S}$ Inci MD, ${ }^{1} \mathrm{~A}$ Akbay $\mathrm{MD},{ }^{2} \mathrm{~V}$ Bertan $\mathrm{MD}^{3}$ \\ ${ }^{1}$ Specialist in Neurosurgery, ${ }^{2}$ Resident in Neurosurgery, ${ }^{3}$ Professor of Neurosurgery, \\ Department of Neurosurgery, School of Medicine, Hacettepe University, Ankara, Turkey.
}

Giant-cell tumours of the spine are very rare. They occur mainly in long bones. We report a patient with a giant-cell tumour of the lumbar spine which had been operated on at another hospital 5 months previously as a protruded lumbar intervertebral disc.

Keywords: giant-cell tumour; lumbar disc; lumbar spine.

\section{Introduction}

Giant-cell tumours (GCT) of bone are rare, and constitute $5 \%$ of all bone tumours. ${ }^{1,2}$ The majority occur in long tabular bones. ${ }^{1-4}$ The lumbar localisation of a giant-cell tumour is also very rare. The purpose of this report is to describe the unusual location of the giant-cell tumour and its magnetic resonance (MR) images.

\section{Case report}

A 46 year old female had low back pain for 6 months. She had been operated at another hospital as having a L4-5 protruded intervertebral disc 5 months previously, but her back pain continued and she developed weakness of her feet. The patient was then admitted to our hospital. The physical examination was within normal limits. On neurological examination, there was severe weakness of dorsal and plantar flexion of her feet. The ankle reflexes were bilaterally absent. Plain radiographs of the lumbosacral area showed a severe destructive lesion of the L5 vertebra. A huge mass of the L5 vertebra was seen in MR imaging (Fig 1).

Preoperatively our diagnosis was an abscess in the previous operating area. To clarify the diagnosis a puncture biopsy was performed under local anaesthesia; the result was negative, therefore she had an operation. When the paravertebral muscles were dissected, a greybrown and highly vascular mass was seen, the laminae and body of L5 vertebra were eroded, and laminectomy was performed. Tumour was removed subtotally with decompression of the

Correspondence: Emek Mah, 4 Cad 70/8, Ankara, Turkey. a

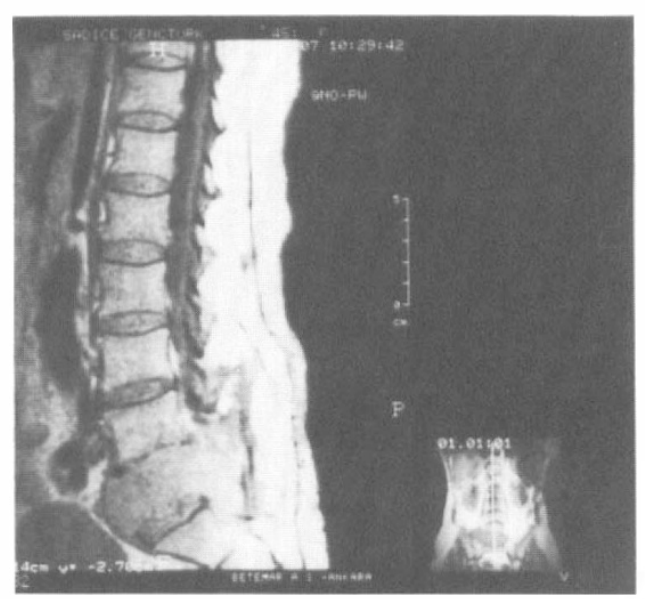

b

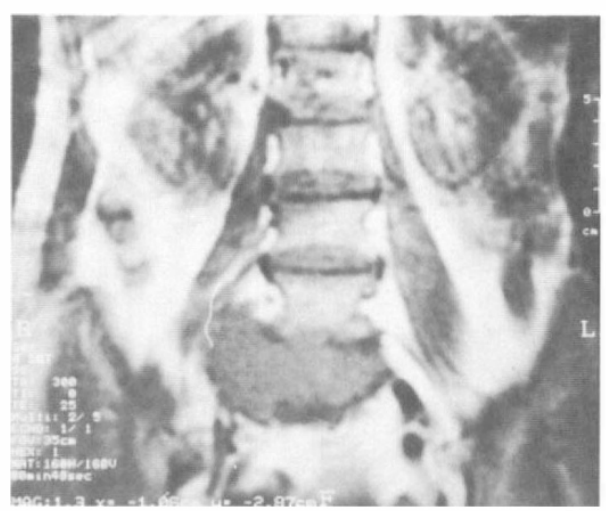

Figure $1 \mathrm{MR}$ images show a huge mass at L5 vertebra. (a) Sagittal section; (b) coronal section. 
fifth lumbar and first sacral nerve roots. The histological appearance of this lesion was identical to that of a giant-cell tumour of bone (Fig $2)$. There was no complication in the postoperative period, and the patient was transported with absolute bed rest for radiation therapy to another hospital.

\section{Discussion}

There are more females than males in most of the reports on giant-cell tumours of bone. ${ }^{1,4-6}$ They usually cause symptoms in the third and fourth decades. ${ }^{2.4 .6 .7}$ The femur, the tibia and the radius are the commonest sites for this tumour, ${ }^{2.6}$ making up $55 \%$ of the lesions. ${ }^{2}$ Other sites are the sacrum, the fibula and the metacarpals. GCT may rarely be multicentric. ${ }^{8}$ Giant-cell tumours of the lumbar vertebrae are very rare, being approximately $0.9 \%$ in the series of Goldenberg. ${ }^{2}$ Lumbar location of the giant-cell tumour is shown in Table I. Lesions in the spine are usually found in the vertebral body, ${ }^{5}$ but with continued growth may extend to involve the laminae, spinous process $^{2,5}$ and even the paravertebral area-as occurred in our patient.

Approximately $10 \%$ of all giant-cell tumours are malignant, ${ }^{9}$ and they may metastasise to other organs. ${ }^{1,2}$ The frequency of metastatic involvement in the large series of benign giant-cell tumours generally has ranged from $1-6 \% .{ }^{10}$ Metastatic lesions occur mainly in the lungs. ${ }^{10-13}$ Solitary metastases to regional lymph nodes, the mediastinum and the pelvis have been reported. ${ }^{10}$

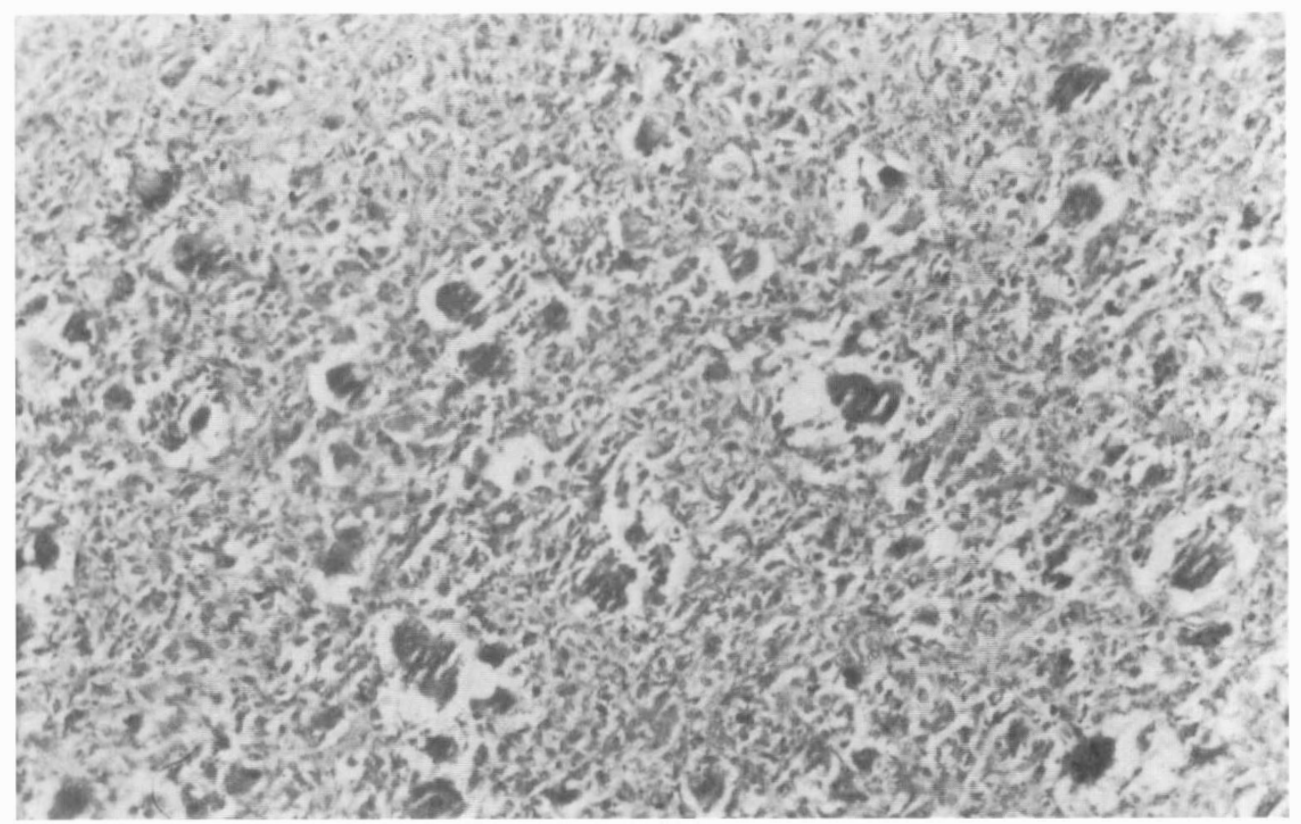

Figure 2 Photomicrograph shows the histology of giant-cell tumor (H.E, X115).

Table I The location of GCT of the spine in the large series

\begin{tabular}{lcccc}
\hline & Cervical & Thoracic & Lumbar & Total cases of GCT \\
\hline Goldenberg $(1970)^{2}$ & 1 & - & $2(0.9 \%)$ & 208 \\
Savini $(1983)^{4}$ & 1 & 3 & $5(1.5 \%)$ & 314 \\
Dahlin $(1985)^{1}$ & 6 & 4 & $6(1.4 \%)$ & 407 \\
\hline
\end{tabular}


Many authors have stated that radiation therapy was important in the malignant transformation of a giant-cell tumour. ${ }^{6,14}$

Total or subtotal excision was the initial procedure for all patients with these lesions. Prior to surgery, embolisation may be performed for the huge vascular mass. ${ }^{5}$ Secondary procedures include radiotherapy and chemotherapy.

The incidence of local recurrence of a giant-cell tumour is still controversial. According to some authors, this incidence is extremely low. ${ }^{4,5,7}$ Other authors have sug- gested that the tendency of local recurrence is high because a giant-cell tumour is a locally aggressive lesion. ${ }^{1,2,6}$ Fifteen months after the operation, there was no local recurrence in our patient.

These spinal tumours may simulate an aneurysmal bone cyst, multiple myeloma, metastatic tumour, osteosarcoma or fibrous dysplasia. ${ }^{1-3}$ As a result, we suggested that a giant-cell tumour should be remembered in the differential diagnosis of a protruded lumbar intervertebral disc, as occurred in our case.

\section{References}

1 Dahlin DC (1985) Giant-cell tumor of bone: Highlights of 407 cases. AJR 144: 955-960.

2 Goldenberg RR, Campbell CJ, Bonfiglio M (1970) Giant-cell tumor of bone: An analysis of two hundred and eighteen cases. J Bone Joint Surg 52(A): 619-664.

3 Mirra JM, Ulich T, Magidson T, Kaiser L, Eckardt J, Gold R (1982) A case of probable benign pulmonary metastases or implants arising from a giant-cell tumor of bone. Clin Orthop 162: 245-254.

4 Savini R, Gherlinzoni F, Morandi M, Neff JR, Picci P (1983) Surgical treatment of giant-cell tumor of the spine. J Bone Joint Surg 65(A): 1283-1289.

5 Biagini R, DeCristofore R, Ruggieri P, Boriani S (1990) Giant-cell tumor of the spine. J Bone Joint Surg 72(A): 1102-1107.

6 Dahlin DC, Cupps RE, Johnson Jr EW (1970) Giant-cell tumor: A study of 195 cases. Cancer 25: 1061-1070.

7 Rosen MP (1991) Giant-cell tumor of the temporal bone. AJR 156: 1290-1292.

8 Potter HG, Schneider R, Ghelman B, Healey JH, Lane JM (1991) Multiple giant-cell tumors and Paget disease of bone: Radiographic and clinical correlations. Radiology 180: 261-264.

9 Murphy WR, Ackerman LV (1956) Benign and malign giant-cell tumors of bone. Cancer 9: 317-339.

10 Rock MG, Pritchard DJ, Unni KK (1984) Metastases from histologically benign giant-cell tumor of bone. $J$ Bone Joint Surg 66(A): 269-273.

11 Bertoni F, Present D, Sudanese A, Baldini N, Bacchini P, Campanacci M (1988) Giant-cell tumor of bone with pulmonary metastasis. Clin Orthop 237: 275-285.

12 Gresen AA, Dahlin DC, Peterson LFA, Payne WS (1973) Benign giant-cell tumor of bone metastasizing to lung. Ann Thorac Surg 16: 531-535.

13 Stargardtes FL, Cooperman LR (1971) Giant-cell tumor of sacrum with multiple pulmonary metastases and long term survival. Br J Radiol 44: 976-979.

14 Resnick D, Kyriakos M, Gleenway GD (1988) In: D Resnick, G Naiwayama, editors. Diagnosis of Bone and Joint Disorders. 2nd ed. W B Saunders, Philadelphia: 3757-3776. 